\title{
Прогностичні фактори тривалості перебування у стаціонарі пацієнтів із гострим коронарним синдромом після екстреної ендоваскулярної реваскуляризаціі міокарда
}

\author{
О. С. Фуркало ${ }^{1,2}$, Д. О. Дзюба ${ }^{1}$, О. А. Лоскутов ${ }^{1,2}$, О. М. Дружина ${ }^{2}$
}

${ }^{1}$ Національна медична академія післядипломної освіти імені П. Л. Шупика, м. Київ,

${ }^{2}$ Інститут серця МОЗ України, м. Київ

\section{Prognostic factors of a stationary stay of patients with an acute coronary syndrome after the emergency endovascular revascularization of myocardium}

\author{
O. S. Furkalo ${ }^{1,2}$, D. O. Dziuba ${ }^{1}$, O. A. Loskutov ${ }^{1,2}$, O. M. Druzina ${ }^{2}$ \\ ${ }^{1}$ Shupyk National Medical Academy of Post-Graduate Education, Kyiv, \\ ${ }^{2}$ Istitute of the Heart, Kyiv
}

\begin{abstract}
Реферат
Мета. Визначити ступінь впливу незалежних один від одного передопераційних чинників на єдиний залежний чинник - тривалість госпіталізації пацієнтів із гострим коронарним синдромом після екстреної ендоваскулярної реваскуляризації міокарда.

Матеріали і методи. Зібрано та статистично опрацьовано дані історій хвороб 40 пацієнтів віком до 60 років (1-ша група) та 40 пацієнтів віком 60 років і старше (2-га група). Методом статистичного опрацювання даних обрано кореляційно-регресійний аналіз.

Результати. У пацієнтів 1-ї групи на тривалість госпіталізації впливали (в порядку зменшення значущості): передопераційні показники гемоглобіну та гематокриту, рівні тропоніну I та загального холестерину, ступінь оклюзії коронарних артерій, індекс маси тіла, фракція викиду лівого шлуночка та об'єм післяопераційної крововтрати. У пацієнтів 2-ї групи єдиним фактором, що істотно вплинув на тривалість госпіталізації, був вік.

Висновки. Предикторами тривалості госпіталізації у віковій групі до 60 років слугують майже всі включені до дослідження незалежні фактори, тоді як у віковій групі 60 років і старше стійка кореляція характерна лише для фактора віку.

Ключові слова: гострий коронарний синдром; коронарне стентування; тривалість госпіталізації; вік; індекс маси тіла; оклюзія коронарних судин; кореляційно-регресійний аналіз.

\section{Abstract}

Objective. To reveal the impact degree of independent one from another preoperative factors on the only one dependent factor - duration of stationary stay in the patients, suffering an acute coronary syndrome, after the emergency endovascular revascularization of myocardium (EERM).

Materials and methods. There were gathered and statistically elaborated the data from the disease histories charts of $40 \mathrm{pa}-$ tients, ageing up to 60 yrs (1-st Group) and 40 patients, ageing 60 yrs old and more (2-nd Group). Correlation-regression analysis was applied as a method for statistical processing.

Results. In the 1-st Group patients several factors have had impact on a hospital stay duration (in order of the significance reduction): preoperative indices of hemoglobin and hematocrit, the levels of troponin I and general cholesterol, the coronary arteries occlusion degree, a body mass index, the left ventricle output fraction and volume of the postoperative blood loss. In patients of 2-nd Group the only one factor, essentially impacting the hospital stay duration, was the patients' age.

Conclusion. For the patients ageing up to 60 yrs old almost all independent factors, included into the investigation, have served as predictors for a hospital stay duration, while in the patients, ageing 60 yrs old and more, a constant correlation was characteristic for the age factor only.

Keywords: an acute coronary syndrome; coronary stenting; stationary stay; age; the body mass index; occlusion of coronary vessels; correlation-regressive analysis.
\end{abstract}

У структурі смертності в Україні серцево-судинні захворювання (СС3) займають перше місце, значно переважаючи онкологічну патологію, травми тощо. Якщо у розвинених країнах світу кількість смертей від ССЗ знижується, то в Україні - це основна причина смертності населення. У 2015 р. від ССЗ померли 680,3 тис. осіб [1].

Кардіохірургія та інтервенційна кардіологія - напрями медицини, покликані найбільш ефективно знизити показники смертності від СС3, а також поліпшити якість і подовжити тривалість життя пацієнтів з цією патологією, що зумовлює стрімкий розвиток медичних технологій, впровадження нових методик лікування і діагностики. Останніми роками дедалі частіше ССЗ лікують з використанням мінінвазивних методик [2].

Стентування є «золотим стандартом» лікування гострого коронарного синдрому (ГКС) у пацієнтів будь-якої вікової групи. Згідно з рекомендаціями Європейського співтовариства кардіологів його можна виконувати після про- 
цедури тромболізису, якщо немає можливості виконати своєчасне втручання [3]. У порівнянні з відкритим оперативним втручанням стентування $є$ менш травматичним, тому тривалість госпіталізації суттєво скорочується, що особливо актуально для пацієнтів працездатного віку [4].

Мета дослідження: визначити ступінь впливу незалежних один від одного перед- та інтраопераційних чинників на тривалість госпіталізації пацієнтів різних вікових груп із ГКС після ендоваскулярної реваскуляризації міокарда.

\section{Матеріали і методи дослідження}

Проаналізовано історії хвороб 80 пацієнтів із ГКС, яким в Інституті серця МО3 України з 16.12.2017 по 06.02.2018 р. було виконано екстрене стентування коронарних артерій.

Усіх хворих розподілили на дві групи: 1-ша - 40 хворих у віці молодше 60 років та 2-га - 40 хворих у віці 60 років і старше.

У 1 -й групі середній вік пацієнтів становив $(45,7 \pm 9,74)$ року, середній індекс маси тіла (IMT) - $(29,98 \pm 4,99)$ кг $\mathrm{M}^{2}$, середня тривалість госпіталізації - $(3,62 \pm 1,96)$ доби. Чоловіків було 32 (80\%), жінок - 8 (20\%). Мультисудинне атеросклеротичне ураження коронарних артерій мали $18(45 \%)$ хворих

У 2-й групі середній вік пацієнтів становив $(67,26 \pm 7,28)$ року, середній IMT - $(27,51 \pm 4,88)$ кг $/ \mathrm{M}^{2}$, середня тривалість госпіталізації - (7,26 6 ,713) доби. Чоловіків було 26 (65\%), жінок - 14 (35\%). Мультисудинне атеросклеротичне ураження коронарних артерій мали 25 (62,5\%) хворих.

Аналізували такі незалежні фактори: вік, IMT, рівні глюкози крові, тропоніну I, загального холестерину, показник фракції викиду лівого шлуночка (ФВ ЛШ), рівні гемоглобіну та гематокриту, різницю до- та післяопераційного рівнів гемоглобіну, ступінь оклюзії коронарних артерій. Єдиним залежним фактором було обрано тривалість перебування пацієнта у стаціонарі. У 28 пацієнтів не було одного або більше зазначених незалежних факторів, тому їх виключили з дослідження.
Статистично матеріал опрацьовували на персональному комп'ютері стандарту РС АТ/АТ. Для вирішення завдань дослідження застосовували такий пакет прикладних програм: «Microsoft Word», «Microsoft Access», «Microsoft Excel» та «Statistica-6».

\section{Результати}

На першому етапі було здійснено статистичну перевірку незалежних факторів на наявність в обох досліджуваних групах мультиколінеарних факторів, тобто таких, що спричинюють викривлення кінцевих результатів аналізу, якщо індекс значущості білыше 0,7. Мультиколінеарність, яка означає, що в множинній регресійній моделі два або більше незалежних факторів пов'язані між собою або мають високий ступінь кореляції, $€$ негативним явищем множинного регресійного аналізу та не дає змоги оцінити вплив кожного окремого фактора на показник. Наявність колінеарних факторів у моделі призводить до таких негативних наслідків: зміщення оцінок параметрів моделі; збільшення коваріації оцінок; незначущості параметрів моделі [5].

Провівши відповідний статистичний аналіз, ми не виявили зазначених факторів.

Оскільки показник тривалості госпіталізації є єдиним залежним показником, ступінь його кореляції із собою дорівнює $100 \%$, або 1.

Представлені в таблиці 1 коефіцієнти парної кореляції для кожного з досліджуваних незалежних факторів відображають ступінь співвідношення незалежних факторів iз показником тривалості госпіталізації. Порівнявши показники в групах пацієнтів віком до 60 та 60 років і старше, ми виявили, що в старшій віковій групі більш суттєво впливали на тривалість госпіталізації такі фактори: IMT, об'єм крововтрати та ступінь оклюзії ПМШГ ЛКА, тоді як у пацієнтів віком до 60 років - ФВ ЛШ та ступінь оклюзіі ОГ ЛКА. Такі результати можна пов'язати з тим, що у пацієнтів у віці до 60 років у середньому вищі адаптаційні та компенсаторні можливості організму.

\begin{tabular}{|c|c|c|}
\hline \multirow{2}{*}{ Фактор } & \multicolumn{2}{|c|}{ Група хворих } \\
\hline & віком до 60 років & віком 60 років і старше \\
\hline Вік, роки & 0,557763 & 0,470566 \\
\hline $\mathrm{IMT}, \mathrm{kr} / \mathrm{M}^{2}$ & $-0,273804$ & 0,169633 \\
\hline Глюкоза крові, ммоль/л & 0,248175 & 0,183510 \\
\hline Тропонін I, нг/мл & $-0,287087$ & $-0,026920$ \\
\hline Загальний холестерин, ммоль/л & 0,024571 & $-0,216407$ \\
\hline ФВ ЛШ, \% & 0,307981 & 0,043572 \\
\hline Гемоглобін, г/л & $-0,008970$ & $-0,371143$ \\
\hline Гематокрит, \% & $-0,003709$ & $-0,106541$ \\
\hline Об'єм крововтрати, мл & $-0,159856$ & 0,325609 \\
\hline \multicolumn{3}{|c|}{ Ступінь оклюзії коронарних артерій, \% } \\
\hline ствола ЛКА & $-0,058824$ & $-0,086424$ \\
\hline ПМШГ ЛКА & $-0,432864$ & 0,036751 \\
\hline ОГ ЛКА & 0,536451 & 0,100097 \\
\hline ствола ПКА & $-0,013431$ & 0,048627 \\
\hline Тривалість госпіталізації & 1,000000 & 1,000000 \\
\hline
\end{tabular}


Таблиця 2. Коефіцієнти регресійного рівняння та помилка у разі відхилення нульової гіпотези для пацієнтів віком до 60 років (початок регресії)

\begin{tabular}{|c|c|c|c|}
\hline \multirow{2}{*}{ Фактор } & \multicolumn{3}{|c|}{ Статистичні показники } \\
\hline & $b^{*}$ & стандартна похибка b* & $\mathrm{p}$ \\
\hline Вік, роки & $-0,02818$ & 0,127710 & 0,836153 \\
\hline $\mathrm{IMT}, \mathrm{kr} / \mathrm{M}^{2}$ & $-0,53054$ & 0,143093 & 0,020697 \\
\hline Глюкоза крові, ммоль/л & $-0,15072$ & 0,096565 & 0,193591 \\
\hline Тропонін I, нг/мл & $-1,25606$ & 0,152041 & 0,001171 \\
\hline Загальний холестерин, ммоль/л & $-1,13909$ & 0,197439 & 0,004480 \\
\hline ФВ ЛШ, \% & 0,31837 & 0,088417 & 0,022743 \\
\hline Гемоглобін, г/л & 5,95888 & 1,088710 & 0,005422 \\
\hline Гематокрит, \% & $-5,86138$ & 1,122597 & 0,006422 \\
\hline Об'єм крововтрати, мл & $-0,31760$ & 0,122830 & 0,060960 \\
\hline \multicolumn{4}{|c|}{ Ступінь оклюзії коронарних артерій, \% } \\
\hline ствола ЛКА & $-0,88473$ & 0,178368 & 0,007705 \\
\hline ПМШГ ЛКА & $-0,60305$ & 0,109866 & 0,005367 \\
\hline ОГ ЛКА & 0,25686 & 0,133638 & 0,126975 \\
\hline ствола ПКА & 0,55127 & 0,151431 & 0,021957 \\
\hline \multicolumn{2}{|l|}{ Примітка. } & $\begin{array}{l}\text { ьоквадратичного відх } \\
\text { чень для певного пар }\end{array}$ & дартизованого \\
\hline
\end{tabular}

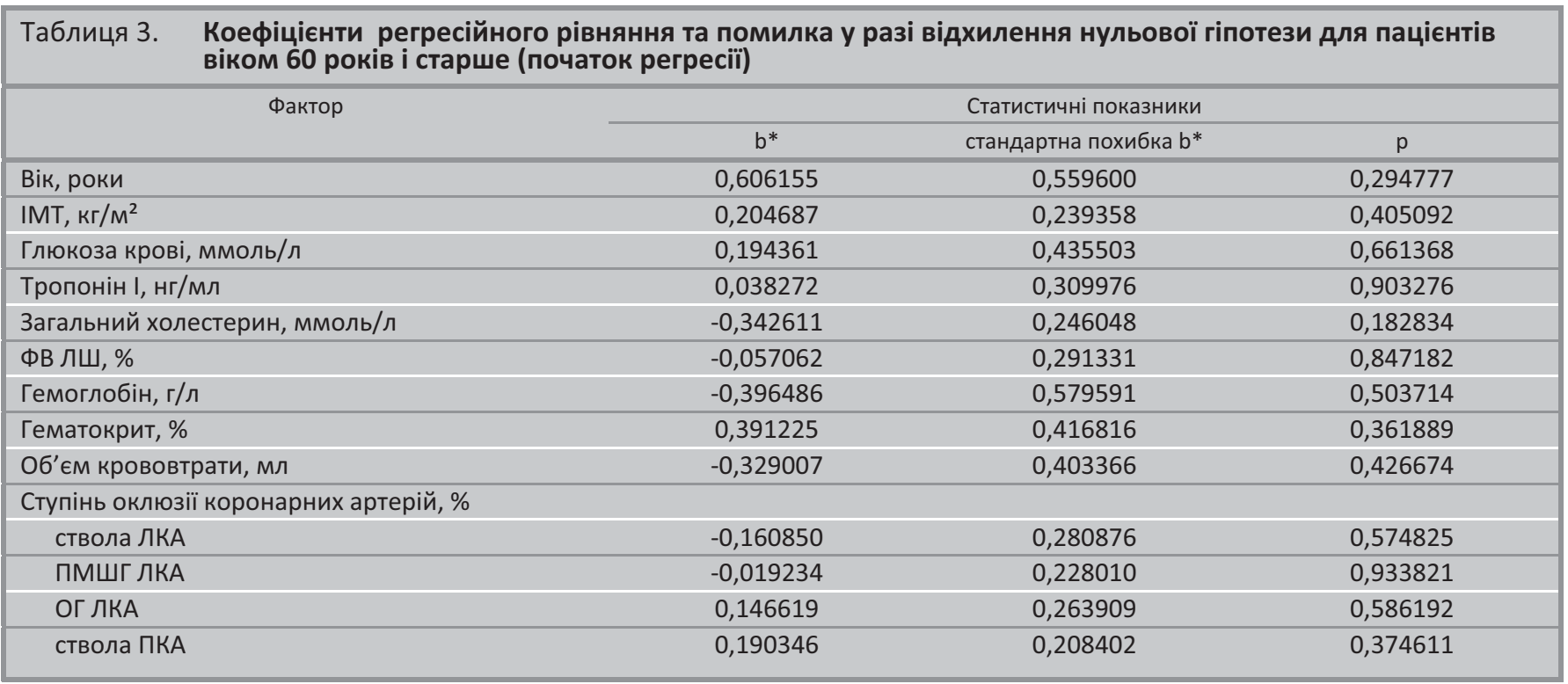

На другому етапі було оцінено попередні результати регресії та визначено коефіціенти кореляції р та бета для кожного з незалежних факторів (табл. 2, 3).

Коефіцієнт р відображає вірогідність помилки у разі відхилення нульової гіпотези. Фактично це вірогідність того, що випадкова величина із заданим розподілом має значення не менше, ніж фактичне значення тестової статистики. Загальноприйнятим вважається значення цього параметра більше 0,05 [6].

Якщо жоден із зазначених незалежних факторів не мав достовірного рівня р (як у старшій віковій групі), висували гіпотезу стосовно відсутності впливу між досліджуваними незалежними факторами та залежним. Для ії підтвердження з аналізу послідовно вилучали всі незалежні фактори починаючи з тих, що мали найвище значення p, і після вилучення кожного фактора модель перебу- довували заново. Якщо результатом такого процесу було вилучення всіх незалежних чинників з аналізу, гіпотезу вважали підтвердженою.

Під коефіцієнтом бета розуміли стандартизований коефіцієнт b*, оскільки незалежні фактори мали різні одиниці вимірювання. Даний показник безпосередньо включали в рівняння регресії та використовували для оцінки індивідуального впливу того чи іншого незалежного фактора на прогнозовану тривалість госпіталізації у разі використання регресійної моделі з прогностичною метою. Величина цього показника для різних незалежних факторів дає змогу встановити, наскільки суттєво зміна заданого предиктора у даного пацієнта вплине на зміну тривалості госпіталізації згідно з побудованою моделлю. Порівняння ж між собою абсолютних значень коефіцієнта $\mathrm{b} *$ дає змогу ранжувати незалежні фактори за ступенем їх значущості та зро- 

Таблиця 4. Коефіцієнти регресійного рівняння та помилка у разі відхилення нульової гіпотези для пацієнтів
віком до 60 років (кінцевий результат аналізу)

\begin{tabular}{|c|c|c|c|c|}
\hline \multirow{2}{*}{ Фактор } & \multicolumn{4}{|c|}{ Статистичні показники } \\
\hline & $b^{*}$ & стандартна похибка b* & $\mathrm{t}$ & $p$ \\
\hline Гемоглобін, г/л & 5,19333 & 1,013999 & 5,12163 & 0,001366 \\
\hline Гематокрит, \% & $-5,12162$ & 1,060736 & $-4,82836$ & 0,001903 \\
\hline Тропонін I, нг/мл & $-1,20151$ & 0,140674 & $-8,54107$ & 0,000060 \\
\hline Загальний холестерин, ммоль/л & $-1,02685$ & 0,166979 & $-6,14957$ & 0,000468 \\
\hline \multicolumn{5}{|c|}{ Ступінь оклюзії коронарних артерій, \% } \\
\hline ствола ЛКА & $-0,85410$ & 0,151899 & $-5,62280$ & 0,000797 \\
\hline ПМШГ ЛКА & $-0,73183$ & 0,093806 & $-7,80157$ & 0,000107 \\
\hline ствола ПКА & 0,67323 & 0,155277 & 4,33569 & 0,003414 \\
\hline $\mathrm{IMT}, \mathrm{kr} / \mathrm{M}^{2}$ & $-0,46887$ & 0,103440 & $-4,53277$ & 0,002691 \\
\hline ФВ ЛШ, \% & 0,39775 & 0,095956 & 4,14514 & 0,004321 \\
\hline Об'єм крововтрати, мл & $-0,38312$ & 0,117754 & $-3,25357$ & 0,013988 \\
\hline
\end{tabular}

бити висновок про переважний вплив певних предикторів на закономірність розподілу залежного фактора [7].

Порівнюючи таблиці 2 та 3, бачимо очевидну різницю між значеннями коефіцієнта р майже для всіх незалежних факторів: якщо у віковій групі до 60 років за попередніми результатами регресіі 9 факторів задовольняли умовам лінійного взаємозв'язку, то у віковій групі 60 років і старше не було жодного такого фактора. Це може свідчити про значну варіабельність клінічних показників у пацієнтів старшої вікової групи.

Далі щодо кожної групи пацієнтів ми вилучили з незалежних факторів той, що мав найбільше значення р, оскільки він статистично призводив до найбільшої кількості помилок у побудованій моделі (щодо вікової групи до 60 років - це вік, щодо вікової групи 60 років і старше це ступінь оклюзії ПМШГ ЛКА), після чого повторили другий етап аналізу для кожної групи. На цьому завершальному етапі аналізу щодо вікової групи 60 років і старше довелося вилучити майже всі досліджувані незалежні чинники, тоді як щодо вікової групи до 60 років було вилучено лише три. Всі показники, що залишилися, мали значення $\mathrm{p}<$ 0,05 та задовольняли вимогам достовірності. Окрім того, було проведено порівняльний аналіз значень коефіцієнта b*, a предиктори, що залишилися, ранжовано в порядку від найбільшого значення коефіцієнта до найменшого, що безпосередньо відповідало впливу кожного з них

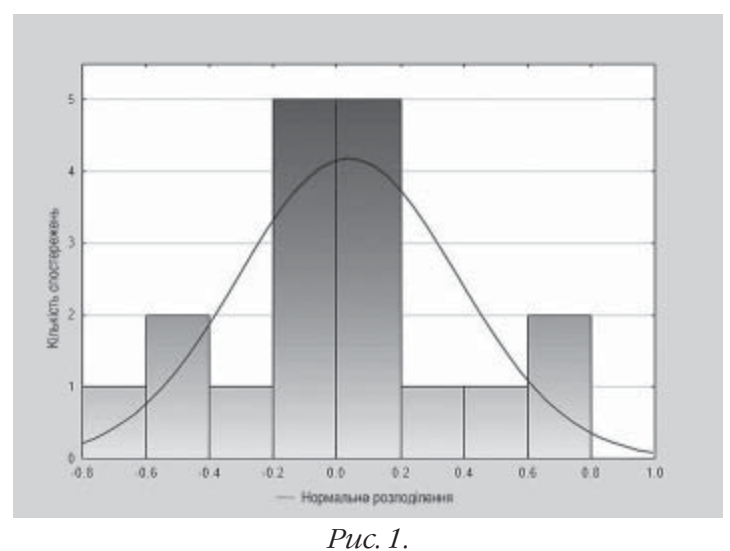

Розподіл залишків для пацієнтів віком до бо років.

\begin{tabular}{|c|c|c|c|}
\hline Таблиця 5. & $\begin{array}{l}\text { Коефіцієнти } \\
\text { та помилка } \\
\text { гіпотези для } \\
\text { і старше (кін }\end{array}$ & $\begin{array}{l}\text { есійного p } \\
\text { відхилен } \\
\text { єнтів віко } \\
\text { й результа }\end{array}$ & $\begin{array}{l}\text { ння } \\
\text { (льової } \\
\text { років } \\
\text { алізу) }\end{array}$ \\
\hline \multirow[b]{2}{*}{ Фактор } & \multicolumn{3}{|c|}{ Статистичні показники } \\
\hline & $b^{*}$ & $\begin{array}{l}\text { стандартна } \\
\text { похибка b* }\end{array}$ & $\mathrm{p}$ \\
\hline Вік, роки & 0,476829 & 0,163225 & 0,006686 \\
\hline
\end{tabular}

на тривалість госпіталізації конкретного пацієнта ( $m a$ бл.4, 5). Як бачимо, кінцевий результат суттєво різнився для обох вікових груп: якщо для вікової групи до 60 років значущими виявилися майже всі показники, то для вікової групи 60 років і старше - лише вік.

Це можна пояснити тим, що основна кількість факторів, що були значущими для пацієнтів молодшої вікової групи, мали менші індивідуальні відхилення від лінійних закономірностей, значущість тих самих факторів для пацієнтів старшої вікової групи набувала більшої різноманітності.

Безпосередня оцінка коефіцієнтів b* у молодшій віковій групі показала, що переважний вплив на тривалість госпіталізації пацієнта мають передопераційні рівні гемоглобіну та гематокриту: вклад кожного з них в рівняння регресії більший, ніж сумарний вклад всіх інших параметрів починаючи з третьої позиції. Наступними за значущістює рівні тропоніну І та загального холестерину, сту-

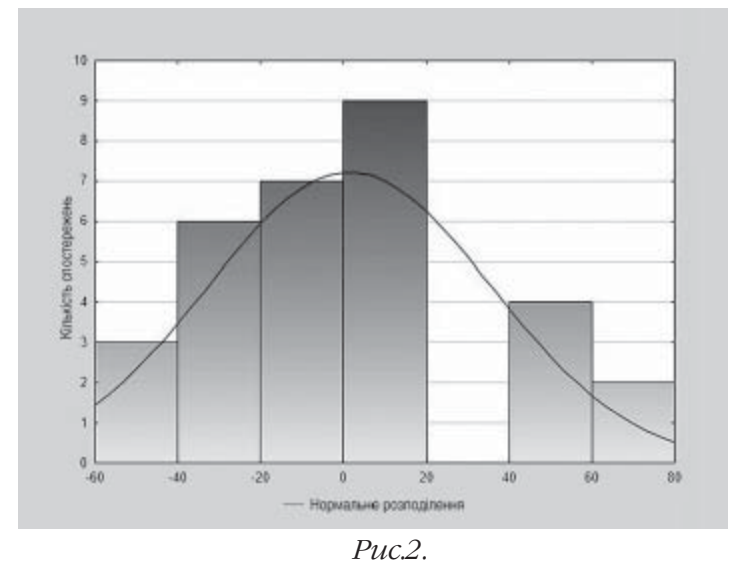

Розподіл залишків для пацієнтів віком 60 років і старие. 
пінь оклюзії коронарних артерій, що мають приблизно однакові значення b*. Показник ФВ ЛШ та об'єм післяопераційної крововтрати найменше впливали на тривалість госпіталізації відносно інших зазначених параметрів.

На третьому етапі аналізували розподіл залишків, тобто оцінювали розташування фактичних значень вибірки у порівнянні з розрахунковими. Якщо фактичні значення відносно розрахункових значень були розподілені нормально, тобто їх розподіл відповідав кривій Гауса, модель вважали дієвою та ефективною у разі подальшого прогнозування значень залежного параметра [6]. У нашому дослідженні розподіл залишків був близький до нормального для обох вікових груп (рис. 1, 2).

Із метою встановлення зв'язку між ключовими передопераційними незалежними чинниками та тривалістю госпіталізації пацієнта ми застосували процедуру множинного кореляційно-регресійного аналізу щодо двох вікових груп пацієнтів із ГКС після стентування і отримали результати, які продемонстрували, що на тривалість госпіталізації пацієнтів у віці до 60 років впливали IMT, рівні загального холестерину та тропоніну I, показник ФВ ЛШ, передопераційні показники гемоглобіну та гематокриту та ступінь оклюзії як лівої, так і правої коронарних артерій, тоді як на тривалість госпіталізації пацієнтів у віці 60 років і старше впливав лише вік.

Така розбіжність свідчить про те, що із збільшенням середнього віку пацієнта більшість досліджуваних передопераційних показників набувають суттєвих індивідуальних відмінностей та великої варіабельності, тоді як із зменшенням середнього віку досліджувані передопераційні незалежні фактори можна у разі комплексного аналізу вважати предикторами тривалості госпіталізації пацієнта.

\section{Обговорення}

Пацієнти похилого віку з діагнозом ГКС потребують особливої уваги в післяопераційному періоді, оскільки доведено входять до групи підвищеного ризику виникнення післяопераційних ускладнень [8, 9]. Результат проведеного дослідження свідчить про суттєво більшу варіабельність незалежних параметрів у 2-й віковій групі, що може бути спричинено відносно більшою кількістю та різноманітністю супутньої передопераційної патології. Хоча об'ємних клінічних досліджень, що мають аналогічний дизайн, нами не було знайдено, окремі автори [10 - 12] також вказують на зв'язок білыш тривалої госпіталізації із старшим віком пацієнта. С. Т. Chin і співавтори [11] виявили зв'язок між білышою тривалістю госпіталізації та об'ємом післяопераційної крововтрати. Подальші дослідження на дану тематику, на думку авторів, мають охоплювати додатковий обсяг передопераційних факторів та визначити, які саме комбінації передопераційних чинників є найбілыш прогностично несприятливими для досліджуваних вікових груп.

\section{Висновки}

1. У пацієнтів з ГКС у віці до 60 років на тривалість госпіталізації впливають IMT, рівні загального холестерину та тропоніну I, показник ФВ ЛШ, передопераційні показники гемоглобіну та гематокриту, а також ступінь оклюзії як лівої, так і правої коронарних артерій.
2. У пацієнтів з ГКС у віці 60 років і старше основним фактором впливу на тривалість госпіталізації є вік.

\section{Підтвердження \\ Фінансування.}

Фінансування публікації власним коштом..

\section{Конфлікт інтересів.}

Автори заявляють про відсутність конфлікту інтересів. Інформація про внесок учасників

О. С. Фуркало - збір та обробка матеріалу, аналіз отриманих даних, написання та оформлення тексту статті; Д. О. Дзюба - дизайн дослідження, редагування тексту статті; О. А. Лоскутов - концепція та дизайн дослідження, аналіз отриманих даних, оформлення тексту статті; О. М. Дружина - відбір вихідного матеріалу.

\section{Згода на публікацію}

Всі автори дали згоду на публікацію цього рукопису.

\section{References}

1. Terenda NO. Vprovadzhennia metodu stentuvannia koronarnykh arterii v Ukraini. Visnyk sotsialnoi hihiieny ta orhanizatsii okhorony zdorovia Ukrainy. 2016;4(70):1-6. doi: 10.11603/1681-2786.2016.4.7543. [In Ukrainian].

2. Dziuba DO, Zhurovska YuM, Loskutov OA. Pytannia anesteziolohichnoho zabezpechennia v interventsiinoi kardiolohii. Medytsyna neotlozhnikh sostoianyi.2017;(1):125-8. doi: 10.22141/2224-0586.1.80.2017.94464. [In Ukrainian].

3. Ibanez B, James S, Agewall S, Antunes MJ, Bucciarelli-Ducci C, Bueno H, et al. 2017 ESC Guidelines for the management of acute myocardial infarction in patients presenting with ST-segment elevation. Rev Esp Cardiol (Engl Ed). 2017 Dec;70(12):1082. doi: 10.1016/j. rec.2017.11.010.

4. Pasala T, Sattayaprasert P, Bhat PK, Athappan G, Gandhi S. Clinical and economic studies of eptifibatide in coronary stenting. Ther Clin Risk Manag. 2014 Aug 2;10:603-14. doi: 10.2147/TCRM.S35664.

5. Astrid S, Dipl Math, Gerhard H. Linear Regression Analysis. Part 14 of a Series on Evaluation of Scientific Publications. Dtsch Arztebl Int. 2010 Nov;107(44):776-82. doi: 10.3238/arztebl.2010.0776.

6. Elyseeva YM, Yuzbashev MA. Obshchaia teoryia statystyky. Moskva: Finansi i statistika; 2005. 656 p. [In Russian].

7. Lukyanova NYu. Statistika: Korreljacionno-regressionnyj analiz statisticheskih svjazej na personalnom kompjutere: Metodicheskie ukazanija k prakticheskim zanjatijam dlja studentov vseh form obuchenija special'nosti «Menedzhment». Kaliningrad: Kaliningr. un-t; 2009. 35 p. [In Russian].

8. Vimalraj BS, Richard H, Ian M, Yuvaraj M, Peter JP. An overview of PCI in the very elderly. J Geriatr Cardiol. 2015 Mar;12(2):174-84. doi: 10.11909/j.issn.1671-5411.2015.02.012.

9. Orenes-Piñero E, Ruiz-Nodar JM, Esteve-Pastor MA. Therapeutic management and one-year outcomes in elderly patients with acute coronary syndrome. Oncotarget. 2017 Sep 24;8(46):80182-80191. doi:10.18632/ oncotarget. 21260

10. Abdissa N, E. Scott. Prediction of Length of Stay Following Elective Percutaneous Coronary Intervention, ISRN Surgery. [Internet]. 2011:6. Article ID 714935. Available from: https://www.hindawi.com/journals/ isrn/2011/714935/. doi: 10.5402/2011/714935.

11. Chin CT, Weintraub WS, Dai D, Mehta RH, Rumsfeld JS, Anderson $\mathrm{HV}$, et al. Trends and predictors of length of stay after primary percutaneous coronary intervention: a report from the CathPCI registry. Am Heart J. 2011 Dec;162(6):1052-1061. doi: 10.1016/j.ahj.2011.09.008.

12. Isik T, Ayhan E, Uluganyan M, Gunaydin ZY, Uyarel H. Predictors of Prolonged In-Hospital Stay After Primary Percutaneous Coronary Intervention for ST-Elevation Myocardial Infarction. Angiology. 2016 Sep;67(8):756-61. doi: 10.1177/0003319715617075.

Отримана 20.10.2018 